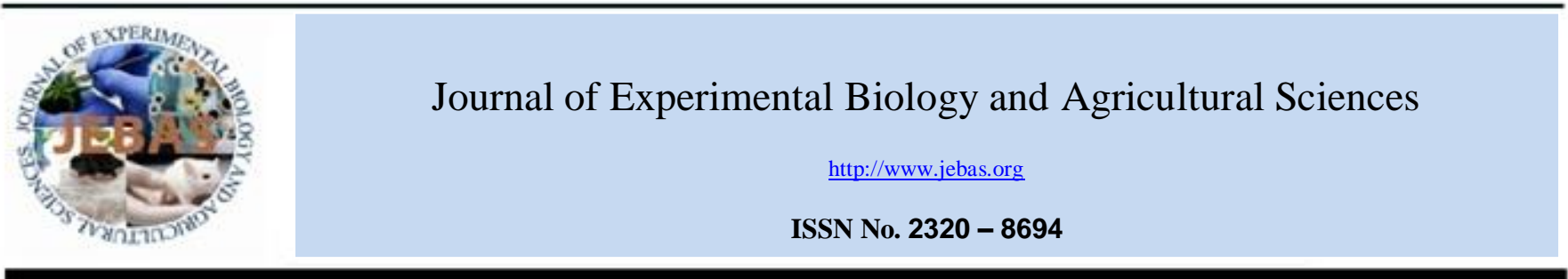

\title{
STATIC ELECTROMAGNETIC FIELD (EMF) OF LOW FREQUENCY ENHANCES SEED GERMINATION AND PLANT GROWTH AT EARLY STAGES OF DEVELOPMENT
}

\author{
Alphy Sabu ${ }^{1 *}$, Priti Dave ${ }^{1}$, N. K. Jain ${ }^{2}$ \\ ${ }^{1}$ Department of Life Sciences, University school of sciences, Gujarat University, Ahmedabad, Gujarat, India - 380009. \\ ${ }^{2}$ Professor and Head, Department of Life sciences, University school of sciences, Gujarat University, Ahmedabad, Gujarat, India.
}

Received - September 19, 2018; Revision - October 22, 2018; Accepted - December 06, 2018

Available Online - December 15, 2018

DOI: http://dx.doi.org/10.18006/2018.6(6).966.972

\section{KEYWORDS \\ EMF \\ Bio - stimulation \\ Germination \\ Exposure \\ Seedling \\ Low frequency}

\begin{abstract}
Magnetic fields have influencedthe life and growth of organisms on this earth. Extremely low frequency electromagnetic radiation is the designation for radiation with frequencies from $1-300 \mathrm{~Hz}$ and its influence on animal and human systems are found to be hazardous. On the contrary, low electromagnetic fields (EMF) have been found to increase the seed germination rates and accelerate the plant growth, protein biosynthesis and root development. The present study aims at determining the impacts of low electromagnetic field (EMF) exposures on seed germination rates and the plant growth phases. For the study, seeds of Pisum sativum, Zea mays, Solanum Lycopersicum, Cyamopsis tetragonoloba, Cajanus cajan were germinated at low electromagnetic fields $(380 \pm 20 \mu \mathrm{T})$. The control groups were kept away from the influence of low EMF while the test groups were germinated under the EMF influence. The observations of present study indicated a significant effect of EMF on germination rates and an enhanced growth period in the test groups. The pot studies were carried out to monitor the seedling growth. The growth rates for the test group seedlings were faster in comparison to the control group. The influence of EMF acting as a biostimulant displays a positive response on seed germination speeding up the germination rates leading to a faster and enhanced plant growth thus reducing the time period for growth leading to a faster crop yield.
\end{abstract}

* Corresponding author

E-mail: alphysabu@gmail.com (AlphySabu)

Peer review under responsibility of Journal of Experimental Biology and Agricultural Sciences.

Production and Hosting by Horizon Publisher India [HPI] (http://www.horizonpublisherindia.in/).

All rights reserved.
All the article published by Journal of Experimental Biology and Agricultural Sciences is licensed under a Creative Commons Attribution-NonCommercial 4.0 International License Based on a work at www.jebas.org.

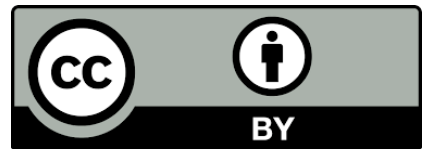




\section{Introduction}

Magnetic fields may have influenced the life and growth of organism on this earth. Extremely low frequency electromagnetic radiation is the designation for radiation with frequencies from 1$300 \mathrm{~Hz}$ and its influence on animal and human systems are found to be hazardous. On the contrary, Earth's geomagnetism is an inevitable attribute to all the organisms' present on the earth. There are possible aspects of geomagnetic fields inducing the growth of species on this plant. So the magnetic fields may have played a role in acting as a bio-stimulant for growth of plants. Plants are considered as better models for investigations in regard to the EMFs as they are ideally suited because of their immobility and their pattern of development which can be constantly monitored in an electromagnetic field (Vian et al., 2007). Still the knowledge about the effects of extremely low frequency magnetic field (ELF MF) on living organisms is limited. The first studies reported on the effects of Magnetic fields (MF) on plants were conducted by Krylov \& Tarakonova in 1960.They proposed an auxin like effect of MF on germinating seeds, by calling this effect as magnetotropism (Krylov \&Tarakonova,1960). A similar study by Boe \& Salunkhe also explains about an Auxin like effect on the ripening of tomato fruits (Boe \& Salunkhe, 1963).

Weak or low MF ranges from $100 \mathrm{nT}$ to $0.5 \mathrm{mT}$, whereas super weak or zero also known as magnetic vacuum is referred to MFs below $100 \mathrm{nT}$. Electromagnetic Fields effects on biological systems have caught attention since its first reporting in 1960 and still pursued. Studies using the EMF for plant growth and stimulating their growth responses were proved (Orchard, 1977; Pittman, 1963; Galland \& Pazur, 2005; Vashisth \& Nagarajan, 2010; Alikamanoglu \& Sen, 2011). Changes in the duration of the cell division phases RNA, protein synthesis under the EMF conditions were altered (Atak et al., 2014; Bertea et al., 2015).This particular study focuses on the use of static EMF with a lower frequency to study the seed germination rates under the influence of EMF growth rates. The plant growth is believed to be enhanced during its growth period and also studies have reported enhanced metabolism (Roux et al., 2008). Germination indices give us the detailing about the ELF MFs' influence on a seed's early growth right from stage 0 (beginning) which helps in monitoring the entire growth period.

\section{Materials \& Methods}

\subsection{Seed collection \& EMF Exposure}

Commercially available seeds of Solanum lycopersicum, Cyamopsis tetragonoloba, Zea mays, Vigna radiata, Cicer arietinum, Cajanus cajan were purchased from APMC market Ahmedabad, Gujarat, India. Control group (seeds) was kept for germination at normal room conditions away from any high EMFs or electric gadgets. Test sets were kept at low electromagnetic fields of $3 \mathrm{~m}$ Tinside a locally built solenoid. Solenoid generated a variable homogeneous magnetic field with frequency of $3 \mathrm{mT}$. A locally built solenoid (560 turns) was used for the static EMF. Fields were strong inside the center of the solenoid. Magnetic field did not alter the temperature of the seeds under stimulation. Three replicates of 50 seeds in each were spread on petri plates containing moist cotton beds. Emergence of radicle and plumule marked the event of seed germination for which seed germination indices were recorded. Germinated seedlings were transferred for pot studies and monitored for 12 weeks.

\subsection{Germination indices}

Growth parameters like shoot length, root length, fresh weight, and dry weight of leaves were studied. Germination rates were also studied for all the seeds kept under the influence of low ELF MF.

1. Mean Germination Time (MGT) was calculated by the method given by Bench et al. (1991), the detail is as follows

$$
\text { MGT }=\sum f \cdot x / \sum f
$$

$f=$ Seeds germinated on day $x$

2. Germination Index (GI) was calculated by the Jones \& Sanders (1987) method, as mentioned below

$\mathbf{G I}=(10 . n 1)+(9 . n 2)+\cdots \ldots .+(1 . n 10)$

$n 1, n 2, \ldots \ldots, n 10=$ No. of germinated seeds on the first, second, and the subsequent days until the $10^{\text {th }}$ day, $10,9, \ldots$ and 1 are weights given to the number of germinated seeds on the first, second, and subsequent days, respectively.

Therefore, the GI emphasizes on both the percentage of germination and its speed. A higher GI value denotes a higher percentage and the rate of germination.

3. Coefficient Velocity of Germination (CVG) Theoretically, the highest CVG possible is 100. In present study it was calculated by Esechie (1994) method

$\mathrm{CVG}=N 1+N 2+\cdots N x \div 100 \times N 1 T 1 \ldots N x T x$

$N=$ No. of seeds germinated each day; $T=$ No. of days from seedling corresponding to $N$

4. Seed Vigour Index was calculated by the following formula 


\section{SVI = Sapling Length $\times$ GP \%}

$\mathrm{GP}=$ Germination Percentage

\subsection{Biochemical indices}

\subsubsection{Total Protein}

Total protein was estimated by Lowry method (Lowry et al., 1951), for this $0.5 \mathrm{gm}$ fresh leaf tissue collected from interveinal area was homogenized in $1.0 \mathrm{ml} 50 \mathrm{mMTris}-\mathrm{HCl}$ buffer, $\mathrm{pH} 8.0$. The homogenate was centrifuged at $15000 \mathrm{~g}$ for 10 minutes and proteins were precipitated from the supernatant with $5 \%$ trichloroacetic acid (TCA).The proteins were pelleted by centrifugation and hydrolyzed in $1 \mathrm{M} \mathrm{NaOH}$ at $37^{\circ} \mathrm{C}$ overnight. An aliquot of the lysate was used to determine the protein content 660(nm).

\subsubsection{Superoxide dismutase}

Superoxide dismutase was estimated by Kakkar et al., method (Kakkar et al., 1984).The leaves $(0.5 \mathrm{gm})$ were ground with $3.0 \mathrm{ml}$ of potassium phosphate buffer, centrifuged at $2000 \mathrm{~g}$ for $10 \mathrm{~min}$ and the supernatant was used for assay. The intensity of the chromogenin the butanol layer was measured at $560 \mathrm{~nm}$ in a spectrophotometer. One unit of enzyme activity is defined by the amount of enzyme that gives 50\% inhibition of Nitrobluetetrazolium dye reduction in 1 minute.

\subsubsection{Lipid peroxidation}

LPO levels in the leaf tissue were determined in terms of malondialdehyde (MDA, a product of LPO) by Heath \&Packer method (Heath \&Packer, 1968). For this $0.26 \mathrm{gm}$ fresh leaf sample was homogenized in $5.0 \mathrm{ml} 0.1 \%$ TCA. This homogenate was centrifuged at $10,000 \mathrm{~g}$ for 5 minutes. The reagent mix containing $4.0 \mathrm{ml} \mathrm{20 \%} \mathrm{TCA} \mathrm{and} 0.5 \%$ TBA were added to $1.0 \mathrm{ml}$ aliquot of supernatant. This mixture was then heated at $95^{\circ} \mathrm{C}$ for 30 minutes and then quickly cooled in an ice bath.

After centrifuging at $10,000 \mathrm{~g}$ for $10 \mathrm{~min}$ the absorbance of the supernatant was read at $542 \mathrm{~nm}$ and the value for the non-specific absorption at $600 \mathrm{~nm}$ was subtracted. The concentration of MDA was calculated using its extinction coefficient of $155 \mathrm{mM}^{-1} \mathrm{~cm}^{-1}$.

\subsubsection{Chlorophyll}

Chlorophyll was extracted in DMSO and the absorbance was read at $663 \mathrm{~nm}$ and $645 \mathrm{~nm}$ by Hiscox \& Israelstam (1979) method. Absorption coefficients were used to calculate the amount of chlorophyll (Arnon, 1949).

Chlorophyll $=12.7(\mathrm{~A} 663)-2.69(\mathrm{~A} 645)$
Chlorophyll $l_{b}=22.9(\mathrm{~A} 645)-4.68(\mathrm{~A} 663)$

Total chlorophyll mg/l = $20.02(\mathrm{~A} 645)+8.02(\mathrm{~A} 633)$

\subsection{Statistical analysis}

Experiments were performed in sets of triplicates. The data were statistically analyzed using one-way analysis of variance (ANOVA). The level of significance was accepted with $\mathrm{P}<0.05$. Quantitative data were expressed as mean \pm SD for all the indices i.e. Germination as well as biochemical.

\section{Results}

\subsection{Germination indices}

A lower value of MGT depicts a faster germination rate which was observed for test sets. Coefficient velocity of germination was higher in test sets which denote the rapid growth in the test sets than controls. Germination Percentage denotes the growth of seeds per day which was found to be lesser in controls group of seeds. Seed Vigor Index were higher in test sets compared to the control sets. Fresh and dry weights were higher for EMF treated seedlings grown under the influence of EMF compared to the controls (not kept in EMF fields) for Z. mays, C. tetragonoloba \& $S$. lycopersicum whereas only for $C$. cajan the control sets were having higher fresh-dry weights (Table 1).

\subsection{Biochemical assays}

The protein content was expressed in $\mu \mathrm{gm} / \mathrm{ml}$ and the protein content estimated by Folin Lowry's method showed increased protein values for $C$. cajan \& V. radiata in the test sets while the controls expressed lesser protein content (Figure 1). While the total MDA concentration in S. lycopersicum, $V$. radiata and $C$. cajan for test groups were greater than controls (Figure 2). In case of SOD Units, it was reported higher for all control sets compared to the test sets (Figure 3). Similarly, total chlorophyll content was higher in test groups than the control groups except for $V$. radiata and C. cajan (Figure 4).

\section{Discussion \& Conclusion}

Studies have pointed out towards EMFs playing a growth promoting role in plant growth right from its germination stage and our results. The calculated germination indices for this study were on a positive scale for the EMF treated seeds e.g. a faster germination rate for EMF treated seeds compared to control seeds not under the influence of any static EMFs which suggests a promotional effect of EMF influence on its growth (Fischer et al. 2004; Cakmak et al., 2010; Shine et al., 2011; Payez et al., 2013 Mahajan \& Pandey, 2014). The dry and fresh weights were also higher than the control seedlings (Florez et al., 2007; Florez et al., 2012). Pre-treating the seeds before sowing also shows improved 
Table 1 Seed germination indices for test group (EMF) and control group

\begin{tabular}{|lccccc|} 
Test and Control & $\begin{array}{c}\text { Mean germination } \\
\text { time } \pm \text { SD }\end{array}$ & $\begin{array}{c}\text { Germination } \\
\text { Index }\end{array}$ & $\begin{array}{c}\text { Coefficient Velocity } \\
\text { of Germination }\end{array}$ & $\begin{array}{c}\text { Germination } \\
\text { Percentage } \%\end{array}$ & Seed Vigour Index \\
\hline Cajanus cajan (Control) & $0.053 \pm 0.77$ & $11.52 \pm 4.9$ & $0.31 \pm 0.02$ & 51 & $6124 \pm 5.74$ \\
\hline Cajanus cajan (test) & $0.090 \pm 1.12$ & $24.27 \pm 10.8$ & $0.35 \pm 0.14$ & 86 & $8036.6 \pm 4.16$ \\
\hline Solanum lycopersicum (control) & $0.59 \pm 0.62$ & $16.44 \pm 12.9$ & $0.18 \pm 0.03$ & 59 & $5340.00 \pm 11.13$ \\
\hline Solanum lycopersicum (test) & $1.22 \pm 1.61$ & $23.43 \pm 16.7$ & $0.28 \pm 0.09$ & 83 & $5870.33 \pm 5.50$ \\
\hline Cyamopsis tetragonoloba (Control) & $0.79 \pm 0.83$ & $10.25 \pm 4.5$ & $0.018 \pm 0.027$ & 53 & $2349 \pm 5.56$ \\
\hline Cyamopsis tetragonoloba (test) & $2.56 \pm 3.71$ & $16.16 \pm 8.6$ & $0.29 \pm 0.09$ & 66 & $3178 \pm 7.21$ \\
\hline Zea mays (control) & $1.62 \pm 2.17$ & $4.29 \pm 1.29$ & $0.23 \pm 0.11$ & 72 & $6440.33 \pm 4.16$ \\
\hline Zea mays (test) & $2.73 \pm 3.78$ & $27.35 \pm 1.59$ & $0.37 \pm 0.25$ & 79 & $7789 \pm 7.81$ \\
\hline Vignaradiate (control) & $0.19 \pm 0.06$ & $13.55 \pm 15.99$ & $0.35 \pm 0.20$ & 78 & $8174.66 \pm 5.13$ \\
\hline Vignaradiate (test) & $0.30 \pm 0.07$ & $18.58 \pm 1.78$ & $0.29 \pm 0.17$ & 89 & $8278 \pm 7.32$ \\
\hline Cicer arietinum (control) & $0.31 \pm 0.15$ & $11.49 \pm 4.76$ & $0.35 \pm 0.20$ & 52 & $7403 \pm 3.60$ \\
\hline Cicer arietinum (Test) & $0.38 \pm 0.21$ & $6.36 \pm 2.52$ & $0.48 \pm 0.32$ & 68 & $8440.66 \pm 7.76$ \\
\hline
\end{tabular}

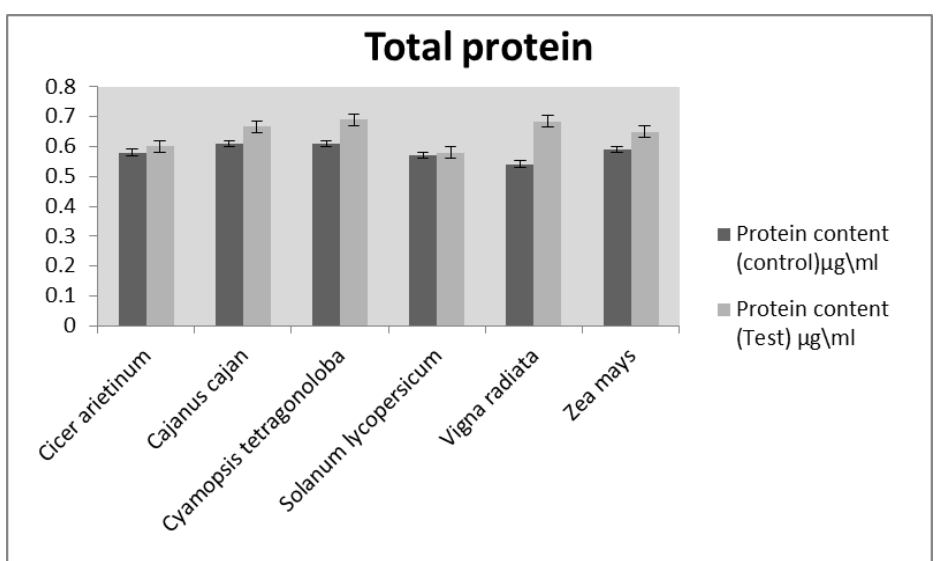

Figure 1 Total protein content for test $\&$ control groups

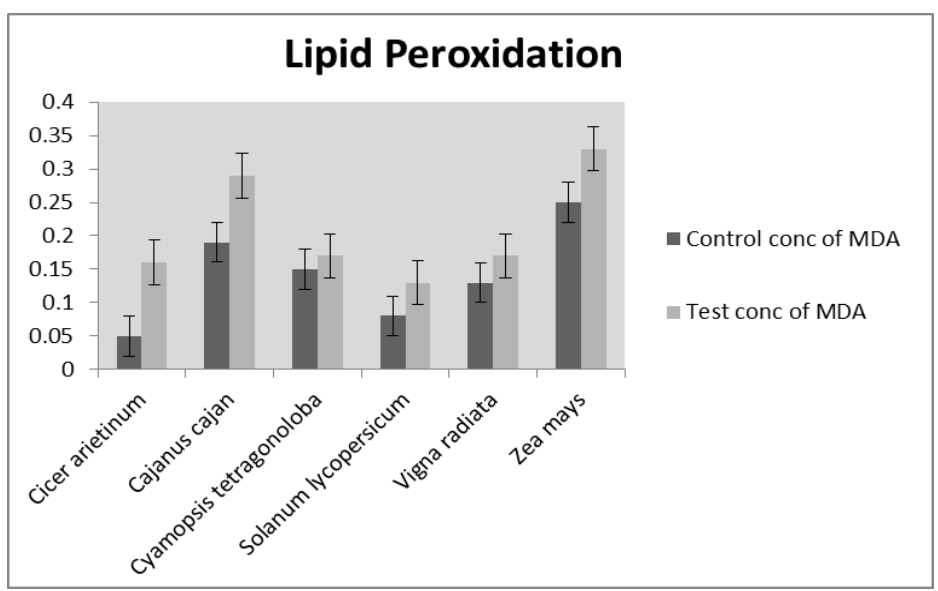

Figure 2 Concentration of MDA - product of LPO for control and test groups results on seed germination and growth factors. Pre-treating the corn seeds with pulsed EMFs for varying time periods have shown an improved germination percentage, seed vigour index, chlorophyll content, leaf area, fresh \& dry weights \& the grain yield at full maturity (Bilalis et al., 2012). However, contrasting results have also been reported which show reduced mean germination time for rice seeds exposed to MF strengths for different time periods or chronic exposure (Florez et al., 2004). The continuous exposure gave better results than intervals of exposure (Carbonell et al., 2011). The physiological parameters in which the early growth stages of the seedling such as the shoot length, root length, fresh weight, dry weight, and leaf area showed uniformity in growth pattern in all the test groups. The results were consistent in all the triplicates. Total protein levels, MDA concentration, Superoxide dismutase (SOD) activity and chlorophyll content in test groups were more significant and considerately increasing in the test groups in comparison to the controls (Radhakrishnan \& Kumari, 2013). This method and its variations i.e. magnetized water for irrigation, magnetizing the seeds before sowing are now being used for agriculture in some countries and varying as well as static magnetic fields and their variations are also

Journal of Experimental Biology and Agricultural Sciences http://www.jebas.org 
being experimented with (Ali et al., 2014; Hozayn et al., 2016; Zúñiga et al., 2016).

In the present study, ELF MF exposure to the seeds right from the beginning to the seedling stage resulted in enhanced growth. The major increases occurred when seeds were continuously exposed to the EMFs. The results we obtained for the germination indices as well as the chlorophyll content show an enhanced growth rate occurring in plants. A deeper understanding into the pathways or gene expressions affected by it could open new ways to fully develop this technique for use on an economically possible way.
New developments in this field are focused on the genetic transformations or epigenetic regulations playing their role in the growth promoting effects of EMFs on plant growth and its development (Rammal et al ., 2014; Sztafrowski et al ., 2017). EMF stimulation could be developed into an efficient method for an agricultural system devoid of the exploitation from the chemical fertilizers and a step towards a sustainable agriculture with better yields. Moreover, to upscale the application of these methods into agricultural systems would need a much wider exploration of EMFs and their effects on plants and other biological systems.

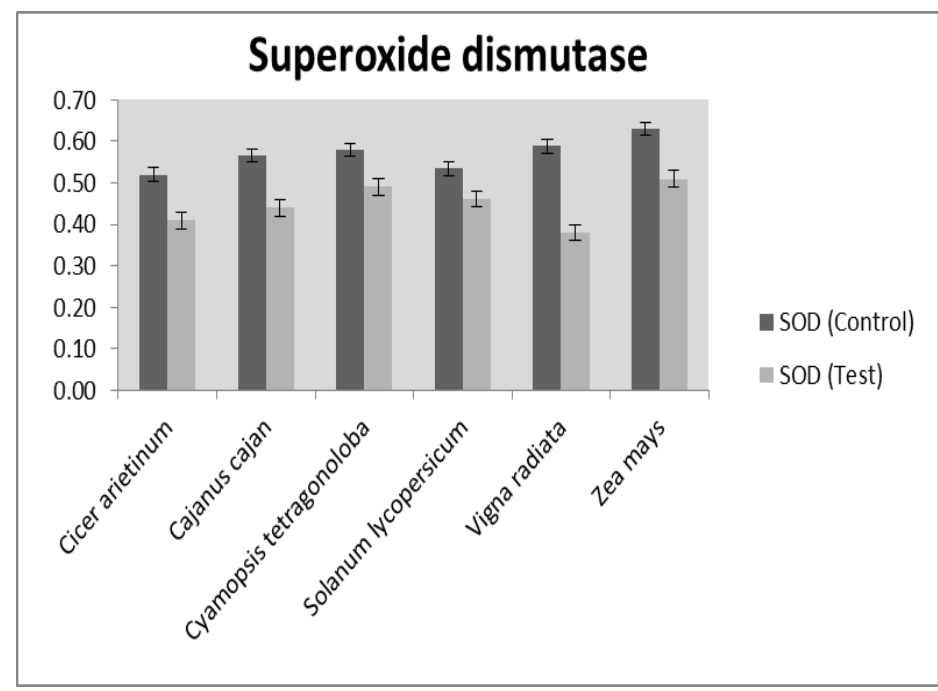

Figure 3 SOD units for control and test groups

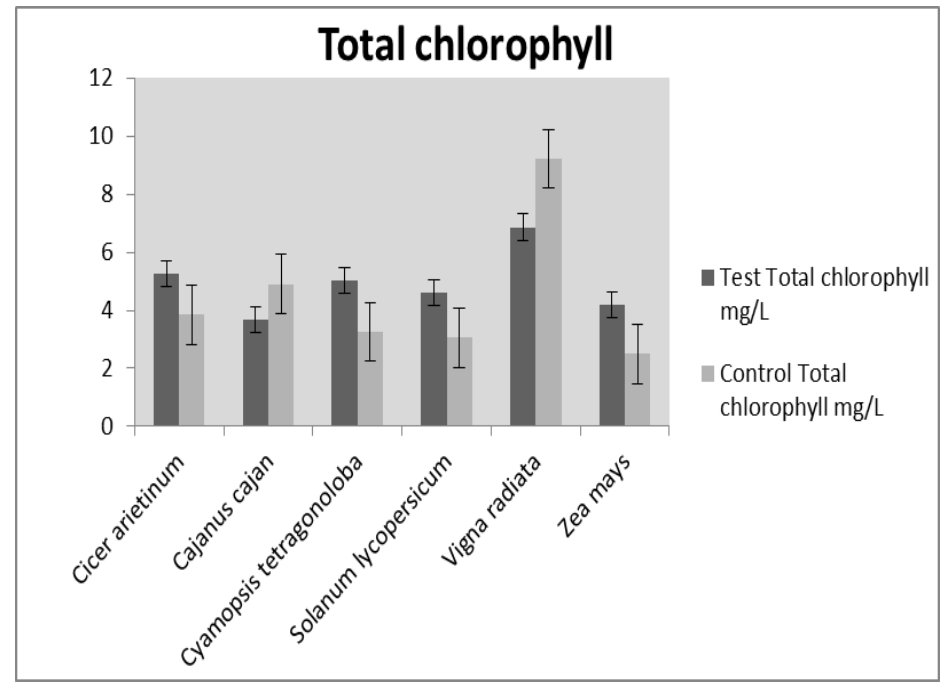

Figure 4 Total chlorophyll $\mathrm{mg} / \mathrm{L}$ or test and control groups

\section{Acknowledgement}

The authors are thankful to Mr. Rizwan Bhaturiwala for his technical support.

\section{Conflict of Interest}

Nil

\section{References}

Ali Y, Samaneh R, Kavakebian F (2014) Applications of Magnetic Water Technology in Farming and Agriculture Development: A Review of Recent Advances. Current World Environment 9 : 695-703.

Alikamanoglu S Sen A (2011) Stimulation of growth and some biochemical parameters by magnetic field in wheat (Triticum aestivum L.) tissue cultures. African Journal of Biotechnology 10 : 10957-10963.

Arnon D (1949) Copper enzymes isolated chloroplasts, polyphenoloxidase in Beta vulgaris Plant Physiology 24:1.

Atak C, Çelik Ö, Olgun A, Alikamanoğlu S, Rzakoulieva A (2014) Effect of Magnetic Field on Peroxidase Activities of Soybean Tissue Culture. Biotechnology \& Biotechnological Equipment 21:166-171.

Bench AR, Fenner M, Edwards P (1991) Changes in germinability, ABA content and ABA embryonic sensitivity in developing seeds of Sorghum bicolor (L.) Moench induced by water stress during grain filling. New Phytologist 118:339.

Bertea CM, Narayana R, Agliassa C, Rodgers CT, Maffei ME (2015) Geomagnetic Field (Gmf) and

Journal of Experimental Biology and Agricultural Sciences http://www.jebas.org 
Plant Evolution: Investigating the Effects of Gmf Reversal on Arabidopsis thaliana Development and Gene Expression. Journal of Visualized Experiments 105:53286.

Bilalis DJ, Katsenios N, Efthimiadou A, Karkanis A (2012) Pulsed electromagnetic field: an organic compatible method to promote plant growth and yield in two corn types. Electromagnetic Biology and Medicine 31:333-343.

Boe AA, Salunkhe DK (1963) Effects of magnetic fields on tomato ripening. Nature 91:199.

Cakmak T, Dumlupinar R, Erdal S (2010) Acceleration of germination and early growth of wheat and bean seedlings grown under various magnetic field and osmotic conditions. Bioelectromagnetics 31:120-129.

Carbonell MV, Flórez M, Martínez E, Maqueda R, Amaya JM (2011) Study of stationary magnetic fields on initial growth of pea (Pisum sativum L.) seeds. Seed Science and Technology 39:673-679.

Sztafrowski D, Aksamit-Stachurska A, Kostyn K, Mackiewicz P, Łukaszewicz M (2017) Electromagnetic Field Seems to Not Influence Transcription via CTCT Motif in Three Plant Promoters. Frontiers in Plant Science 8: 178.

Esechie HA (1994) Interaction of salinity and temperature of the germination of sorghum. Journal of Agronomy and Crop Science 172:194.

Fischer G, Tausz M, Kock M, Grill D (2004) Effect of weak 16 $2 / 3 \mathrm{HZ}$ magnetic fields on growth parameters of young sunflower and wheat seedlings. Bioelectromagnetics 25:638-641.

Florez M, Carbonell MV, Martinez E (2007) Exposure of maize seeds to stationary magnetic fields: Effects on germination and early growth. Environmental and Experimental Botany 59:68-75.

Florez M, Carbonell MV, Martínez E (2004) Early sprouting and first stages of growth of rice seeds exposed to a magnetic field. Electromagnetics 23:157-166.

Flórez M, Martinez E, Carbonell MV (2012) Effect of magnetic field treatment on germination of medicinal plant. Polish Journal of Environmental Studies 21: 57-63.

Galland P, Pazur A (2005) Magnetoreception in plants. Journal of Plant Research 118: 371-389.

Heath RL, Packer L (1968) Photoperoxidation in isolated chloroplasts. I. Kinetics and stoichiometry of fatty acid peroxidation. Archives in Biochemistry and Biophysics 125:189-198.
Hiscox JD, Israelstam GF (1979) A method for the extraction of chlorophyll from leaf tissue without maceration. Canadian Journal of Botany 57:1332-1334.

Hozayn M, Abdallha, M, MonemAAbd El, El Saady A, Darwish A (2016) Applications of magnetic technology in agriculture: A novel tool for improving crop productivity Canola. African Journal of Agricultural Research 11: 441-449.

Jones K, Sanders D (1987) The influence of soaking pepper seed in water or potassium salt solutions on germination at three temperatures. Journal of Seed Technology 11:97-102.

Kakkar P, Das B, Viswanathan PN (1984) A modified spectrophotometric assay of superoxide dismutase. Indian Journal of Biochemistry and Biophysics 21:130-132.

Krylov AV, Tarakonova GA (1960) Plant Physiology. Fiziologiyarastenii 7:156.

Lowry OH, Rosebrough NJ, Farr AL, Randall RJ (1951) Protein measurement with the folin phenol reagent. Journal of Biological Chemistry 193:265-278.

Mahajan TS, Pandey OP (2014) Magnetic-time model at offseason germination. International Agrophysics 28: 57-62

Orchard T (1977) Estimating the parameters of plant seedling emergence. Seed Science and Technology 5:61-69.

Payez A, Ghanati F, Behmanesh M, Abdolmaleki P, Hajnorouzi A, Rajabbeigi E (2013) Increase of seed germination, growth and membrane integrity of wheat seedlings by exposure to static and electromagnetic fields. Electromagnetic Biology and Medicine 32: 417-429.

Pittman UJ (1963) Magnetism and plant growth. I. Effect on germination and early growth of cereal seeds. Canadian Journal of Plant Science 43:513-518.

Radhakrishnan R, Kumari BDR (2013) Influence of pulsed magnetic field on soybean (Glycine max L.) seed germination, seedling growth and soil microbial population. Indian Journal of Biochemistry \& Biophysics 50: 312-317.

Rammal M, Jebai F, Rammal H, Joumaa WH (2014) Effects of long term exposure to RF/MW radiations on the expression of mRNA of stress proteins in Lycopersiconesculentum. WSEAS Transactions on Biology and Biomedicine 11: 10-14.

Roux D, Vian A, Girard S, Bonnet P, Paladian F, Davies E, Ledoigt G (2008) High frequency (900 MHz) low amplitude (5 V $\mathrm{m}-1)$ electromagnetic field: a genuine environmental stimulus 
that affects transcription, translation, calcium and energy charge in tomato. Planta 227: 883-891.

Shine MB, Guruprasad KN, Anand A (2011) Enhancement of germination, growth and photosynthesis in soybean by pretreatment of seeds with magnetic field. Bioelectromagnetics $32: 474-478$.

Vashisth A, Nagarajan S (2010) Effect on germination and early growth characteristics in sunflower (Helianthus annuus) seeds exposed to static magnetic field. Journal of Plant Physiology 167: 149-156.

Vian A, Faure C, Girard S, Davies E, Hallé F, Bonnet P, Ledoigt G, Paladian F (2007) Plants respond to GSM-like radiations. Plant Signaling \& Behavior 2 : 522-524

Zuniga $\mathrm{O}$, Benavides JA, Ospina-Salazar DI, Jiménez CO, Gutiérrez MA (2016) Magnetic treatment of irrigation water and seeds in agriculture. Ingeniería y competitividad $18: 217-232$. 